\title{
The Relational Aspects of Luxury Consumption in Brazil: The development of a Luxury Customer Relationship Perception Scale and the Analysis of Brand Personality Influence on Relationship Perception on Luxury Fashion Brands
}

\author{
Fernanda Scussel ${ }^{1,+(1)}$ \\ ${ }^{1}$ Universidade Federal de Santa Catarina, Florianópolis, SC, Brazil \\ Gisela Demo ${ }^{2, \Omega(1)}$ \\ ${ }^{2}$ University of California, California, Estados Unidos
}

\begin{abstract}
The main objective of this article is to develop a scale to measure relationship perception among customers of luxury fashion brands in Brazil. We followed Churchill's (1979) and Rossiter's (2002) guidelines on scale development, emcompassing interviews and the creation of a pilot version of the scale, that went through two purification processes - exploraroty and confirmatory factor analysis. The Luxury Customer Relationship Perception Scale is a 20 items instrument composed by three primary factors (brand experience, customer loyalty and brand image) and a second order factor (customer relationship perception), with good psychometric indices. As a secondary objective, we tested the relation between the dimensions of brand personality on relationship perception in the luxury context, confirming a prediction relation between these variables. Regarding our contributions, we propose a new metric for marketing literature, which enables future relational studies with other consumer behavior constructs. Then, we empirically show the impact of brand personality on relationship perception, filling a gap on literature that can also help the research on the antecedents of relationship marketing. Lastly, we analyse luxury consumption in an emerging country, a topic of growing interest in literature, bringing out the aspects of the relationship between luxury brands and Brazilian customers.
\end{abstract}

Keywords: relationship marketing; brand personality; relationship perception; luxury.

\section{INTRODUCTION}

Luxury consumption has changed over the years from a traditional consumption model to a relationship-based model, oriented towards a new consumption society that understands buying as a personal and holistic experience (ATWALL; WILLIAMS, 2009). Recent findings on luxury fashion market have been directing research on this matter to explore the concept of value, created by interactions between customers and brand, and one of the most important elements of brand competitive advantage (CHOI, KO, KIM, 2016). In this sector, the increase of customer value is connected to the management of intangible
Corresponding author:

† Universidade Federal de Santa Catarina, Florianópolis, SC, Brazil E-mail: fbcardoso@gmail.com

$\Omega$ University of California, California, Estados Unidos

E-mail: giselademo@gmail.com

Received: 01/31/2018.

Revised: 04/20/2018.

Accepted: 05/28/2018.

Published Online: 12/05/2018.

DOI: http://dx.doi.org/10.15728/bbr.2019.16.2.5 
aspects, such as customers' perceptions and experiences when buying luxury brands (KIM; PARK; LEE; CHOI, 2016).

These statements lead us to relationship marketing, an organizational philosophy based on trust, satisfaction and loyalty that addresses the engagement between brands and its consumers, providing benefits for both (SCUSSEL; PETROLL; SEMPREBOM; ROCHA, 2017). Under consumption research, a relationship can be defined as a series of interconnected interactions between two parties, demanding the analysis of the involved actors and the particularities of such interactions (FOURNIER, 1998). Nevertheless, there is no relationship if the customer does not say so (GRÖNROOS, 2009). In this sense, customer relationship perception becomes a valuable construct: it revals the most relevant relational aspects for customers (DEMO; ROZZETT, 2013). This perception comprehends technical and functional issues, but also behavioral aspects regarding the interactions with a company or a brand (GRÖNROOS, 2017).

Luxury consumption drivers are uniqueness, product quality, prestige and status seeking and the symbolic meanings provoked by luxury, encompassing its hedonic and emotional potential (ROUX; TAFANI; VIGNERON, 2017). Specific in the domain of luxury fashion brands, formed by clothes, shoes and accessories, there is a high level of involvement with fashion wear, encompassing pre-purchase information seeking, buying experience and post-purchase treatment (WU; CHANEY; CHEN; NGUYEN; MELEWAR, 2015). In accordance to this, Choi et al. (2016) affirm that luxury fashion brands segment frames a special context that can benefit from strong relationships with customers.

There is a growing need in understanding luxury consumption in emerging economies, such as the countries in the BRIC - Brazil, Russia, India and China (SEO; BUCHNANOLIVER; CRUZ, 2015). In Brazil, luxury market finds a great expansion opportunity due to the imaginary of customers in emerging markets as they use shophisticated products as distinctive symbols to elevate self-steem, to build a social identity and to aspire new social positions (BIZARRIAS; STREHLAU; BRANDÃO, 2017). Considering the above, we wonder: how do Brazilian consumers relate with luxury brands? What is their perception on the relationship they have with luxury fashion brands?

On that account, the main goal of this work is to propose a Luxury Customer Relationship Perception Scale, which allows us to access the aspects that form relationship perception in the context of luxury fashion brands in Brazil.

Howerer, the idea that relational benefits would help developing long-term relationships is limited: consumer bonds are created not only by utilitarian means, but also by intangible aspects (FOURNIER, 1998). In this way, there is the idea that consumers perceive brands in the same way they perceive people (KERVYN; FISKE; MALONE, 2012). When brands are seen as having character traits, customers are more likely to relate to those brands with which they feel more affinity in terms of personality (BRITO, 2010). These arguments direct us to the brand personality concept, defined as the set of human characteristics associated with a brand, allowing associations in consumers' minds, essential to build a relationship between consumer and brand (AAKER, 1997).

In light of that, we build a second question to this research: how does brand personality influences relationship perception? Studies have focused on validating the relationship between consumers and brands (FOURNIER; ALVAREZ; 2012; PARK; EISINGERICH; PARK, 2013), but the relation between brand personality and relationship perception remains as a literature gap, which we intend to fill with this work. Hence, our secondary objective is to evaluate the relation between brand personality and customer relationship perception in the context of luxury brands. 


\subsection{Customer Relationship Perception}

A recent definition states that relationship marketing is as a business philosophy that aims to promote interaction between customers and companies in a holistic way, creating value to the customer by the engagement between them (SCUSSEL et al., 2017). The central concept of this definition is interaction, and managing these interactions enables firms to develop long-term relationships with customers. According to Grönroos (2009), companies need to understand their needs, habits and lifestyles in order to create attractive value proposals, and relationship marketing and its interactional and holistic approach gives companies the tools to achieve that.

Recently, Grönroos (2017) proposed a relationship marketing theoretical model composed by three processes. The first one concerns customers' value creation processes, a set of all encounter points between company and customer that enables relational benefits to arise. The second one is the interaction process, regarding the actions and interactions that aim to maintain and enhance their relationship. Lastly, there is the communication process, where sales, marketing communication, digital marketing, mass communication and formal offers are presented to the customers so they can build the image of the company and their perceptions about it.

From a consumer perspective, relationship marketing is formed by three main defining constructs: customer trust, customer satisfaction and loyalty (SCUSSEL et al., 2017). The authors say that companies need to show customers the relational benefits they can have, in order to help them to decide if they want to relate with the brand. As Grönroos (2009) explains, the decision about relationship with a brand is a customer decision. To this scholar, companies can offer customers value proposals, provided by relational benefits customers perceive, but only customers can say if they relate or not with a company or a brand. In this sense, interactions are the basis of a relationship, once they are opportunities for companies to have access to customers' information, which will guide companies' efforts on value creation (GRÖNROOS, 2009).

Considering the above, customer relationship perception presents itself as an important construct to relationship marketing literature. Research on this topic acknowledges that both parties - customer and company - need to perceive their share in a relationship (WONG; SOHAL, 2002; SOUZA NETO; MELLO, 2009). As stated by Grönroos (2009), a relationship does not exist because the firm says so, but only when the customer recognizes the nature of this bond. Literature on consumer behavior endorses this: when customers perceive to have a relationship with a brand and feel they can benefit from it, they are more likely to buy than when they do not feel in a relationship with the brand (LAFFERTY; GOLDSMITH; HULT, 2004; BECKER-OLSEN; TAYLOR; HILL; YALCINKAYA, 2011). Recent findings show the way companies manage their interaction with customers affects not only the way customers perceive their relationship but also their willingness to continue the relationship (GRÖNROOS, 2017).

Rozzett and Demo (2010) conducted studies in Brazil and in the United States (DEMO; ROZZETT, 2013) to develop and validate a scale to measure customer's perception of their relationships with companies, obtaining reliable psychometric indices. Recent literature points out studies of validation of their work on specific sectors, such as amusement parks (VASCONCELOS; DEMO, 2012), electronic games (DEMO; BATELLI; ALBUQUERQUE, 2015) and the beverage sector (DEMO; LOPES, 2014). These studies certify the internal structure of the scale, proving its ability to measure customer relationship perception. 


\subsection{Brand Personality}

According to Fournier (1998), people increasingly tend to build relationship with brands based on the compatibility between consumer and brand, attributing brands with human characteristics. On this matter, Aaker and Joachimsthaler (2000) admit that one way that consumers can identify a brand in their minds is through the perspective of the brand as a person, which places brand personality as a central element.

Since brands are targets of preferences, expectations, and attributions, Caprara, Barbaranelli, and Guido (2001) argue that it is plausible to use the same heuristic that leads to the formation of an impression about a person to the formation of an impression about a brand. For Aaker (1997, p. 347), brand personality is the "set of human characteristics associated with a brand," where the symbolic use of brands is explained by the fact that consumers assign brands with human personality traits that identify and differentiate those brands.

Under marketing studies, recent empirical production highlights brand personality as an important component of competitive differentiation strategies (MALAR; NYFFENEGGER; KROHMER; HOYER, 2012), bringing out the influence of symbolic consumption in the design of business strategies (NOBRE; BECKER; BRITO, 2010). In addition, we found a body of research on the effects of brand personality on brand positioning strategies (KIM; SUNG, 2013), the development of persuasion in advertising (PARK; JOHN, 2012), and the use of celebrities for brand endorsement, exploring the influence of brand personality traits (ARSENA; SILVERA; PANDELAERE, 2014). These findings reveal brand personality as a predictor of a series of marketing and consumer behavior constructs, yet no studies were found on the relation between brand personality and relationship perception.

Regarding brand personality measurement, Aaker (1997) proposed the development of Brand Personality Dimensions, a scale in which different types of brand personality can be identified. The results indicate that individuals in the United States perceive brands in terms of five personality dimensions: Sincerity, Excitement, Competence, Sophistication, and Ruggedness. Literature agrees that the research tradition in brand personality took a new direction with Aakers's scale, noting that brand personality consists of a specific construct for each culture (AZOULAY; KAPFERER, 2003).

Muniz and Marchetti (2012) conducted a validation study of Aaker's original scale (1997) in Brazil, identifying five brand personality dimensions in the Brazilian context: Credibility, Joy, Audacity, Sophistication, and Sensitivity. Nonetheless, there are still only a few studies on brand personality in Brazil (SCUSSEL; DEMO, 2016). These authors justity the need to develop works in this topic, once it can help develop consumer beharvior understanding in this context. They also state that the instrument validated by Muniz and Marchetti (2012) is a first step on the development of brand personality studies in Brazilian marketing literature, allowing case studies and relational researches with other marketing constructs.

\subsection{LuXURy Fashion Market}

The luxury industry engender a highly competitive market, which has expanded the last decade, with notable participation of BRIC economies and a shift in luxury consumption habits (KO; PHAU; AIELLO, 2016). In this sense, it is paramount that investigations on the luxury segment consider the effects of the country on customer's perceptions, attitudes and willingness to buy luxury brands, especially those focused on fashion apparel (CHEAH; PHAU; ZAINOL, 2016). In Brazil, luxury brands set a promising market, once hedonic values are very important to Brazilian customers, whose sense of identity and self-image are associated with the possession of high prestige and power products (CAMPANARIO; STREHLAU, 2016).
BBR

16,2 
BBR

16,2

178

In luxury fashion brands segment, value creation is associated with the development of strong bonds with customers through unique interactions, based on emotional and cognitive aspects (CHOI et al., 2016). This means that luxury customers' evaluations are created from their perceptions, especially those related to service quality, the anticipation of their needs and the experience in retail stores (KIM et al., 2016). In addition, luxury customers value hedonic benefits and tend to be more loyal to brands that fulfill their consumption goals and needs (STATHOPOULOU; BALABARIS, 2016).

Nevertheless, empirical research is lacking on relational aspects on luxury fashion brands market (CHOI et al., 2016). Along these lines, Ko, Phau and Aiello (2016) affirm that luxury brand market configures a growing research arena, especially in the fast-changing global economy and the changes in luxury consumption in emergent cultures.

\section{METHOD}

To achieve our objectives, two studies have been conducted. Study 1 was planned to build the Luxury Customer Relationship Perception Scale (LCRP Scale). To capture which dimensions of brand personality have an effect on relationship perception in the context of luxury fashion brands, we considered brand personality as the independent variable and relationship perception as the dependent one, testing this relation on Study 2.

\subsection{DeVelopment and validation of THe Luxury Customer Rela- Tionshit Perception Scale - LCRP Scale (Study 1)}

In the LCRP Scale development, guidelines provided by Churchill (1979) and Rossiter (2002) were followed. According to Diamantopoulos (2005) and Finn and Kayande (2005), both procedures have strengths and limitations. In face of this, Oliveira and Veloso (2015) proved that a combination of both brings advantages to the scale development process. Hence, Study 1 was planned in seven steps: construct definition; empirical understanding of the construct; generation of a pilot version of the scale; scale purification; new scale purification, with a new sample; and proposition of final items.

The first step is construct definition, which takes us back to the theoretical references visited on relationship marketing to define Customer Relationship Perception. For the empirical comprehension of the construct, both Churchill (1979) and Rossiter (2002) agree that to acess construct domain, interviews can provide the comprehension of the phenomena under investigation. Considering it is difficult to access luxury brands clients, we resorted to the snowball strategy, a non-probabilistic sampling procedure that uses reference chains and is usefull to research inpenetrable social groupings (ATKINSON; FLINT, 2001). According to these authors, snowball sampling has an explorative nature and offers practical advantages to conduct interviews, which makes it adequate to our study's objective.

Hence, we conducted ten interviews with frequent buyers of luxury fashion brands aged between 29 and 49 years, all with college education. The number of respondents was defined by the saturation criterion, which occurs when the responses begin to repeat and no new data is generated, determining that the sample is sufficient (BARDIN, 2014). We used an interview scrip to promote a conversation with them, following the guidance of Castillo-Montoya (2016), with interview questions related to their relationship perception on luxury fashion brands. With the authorization of participants, interviews were recorded, transcripted and analyzed through thematic categorical content analysis as proposed by Bardin (2014).

For the generation of a pilot version of the scale, we used two methods: a previously validated scale (DEMO; ROZZETT, 2013) and the results from content analysis made on the previous step. Following the instructions from Churchill (1979) and Rossiter (2002), the pilot version was submitted to semantic analyses and judges' analyses. For the semantic 
analyses, a sample of 20 luxury fashion brands consumers assessed the clarity of the items. Simultaneously, eight specialists in marketing conducted judges' analysis to determine if the proposed items referred to the construct relationship perception specifically in the luxury brands context.

As Churchill (1979) states, the next step is scale purification, when the items from the LCRP Scale pilot version were submitted to exploratory factor analysis (EFA). For this, we followed the recommendations by Hair et al. (2009) and Tabachnick and Fidell (2013), who suggest that the sample size for EFA is between 5 and 10 subjects per item as a rule of thumb.

The subsequent move proposed by Churchill (1979) is a new purification of the scale. We performed confirmatory factor analysis (CFA); using covariance based structural equation modeling (CB-SEM), maximum likelihood estimation method, with the use of AMOS statistical program. Based on Coltman, Devinney, Midgley and Venaik's (2008) criteria, we built a reflective measurement model, once the customer relationship perception is an existing construct and we expect its dimensions reflect customers' perception about their relationship with brands and organizations.

Hair et al. (2009), Kline (2011), and Byrne (2009) agree that there must be between 10 and 20 subjects per variable for the CFA, but a minimum of 200 subjects is recommended. To conduct the CFA, the model validated with EFA was used. The last step concerns the proposition of final items of the scale.

\subsection{VERIFICATION OF THE MODEL AJUSTMENT BETWEEN BRAND PERSON- ALITY AND CUSTOMER RELATIONSHIP PERCEPTION (STUDY 2)}

To analyze the relation between brand personality and relationship perception on luxury fashion brands context, we used a brand personality scale validated in Brazil by Muniz and Marchetti (2012) and the final version of the LCRP Scale developed and validated in Study 1.

To verify the prediction between variables we used path analysis, also known as a structural model test, which aims to estimate relationships between variables through structural equations modeling, using maximum likelihood estimation criterion to check the fit of the model. The main function of the path analysis is the specification and estimation of linear relationships between variables (KLINE, 2011).

For behavioral sciences, it is important to select a minimum sample that has greater statistical power than 0.80 (COHEN, 1992). Utilizing the GPower 3.1 program and considering the predictor variable, brand personality, with five dimensions, we obtained a minimum sample of 138 subjects, considering $\alpha=0.05$ and 5 predictors.

\subsection{QUANTITATIVE DATA COLLECTION AND SAMPLING PLAN}

Data was collected for both studies at the same time, once the questionnaire was composed by the pilot version of LCRP Scale (developed on Study 1) and 28 items from Brand Personality Scale (MUNIZ; MARCHETTI, 2012). Four sociodemographic items were added in order to characterize the sample. Final questionnaire had 72 items.

To proceed with this paper, we investigated frequent luxury brand female buyers, once research demonstrated there are differences between genders in luxury consumpsion, revealing that women represent $60 \%$ of consumers of the luxury market (ROUX; TAFANI; VIGNERON, 2017). Only Brazilian women who had already purchased a luxury brand could complete the online questionnaire. The first question requested them to write the name of a luxury fashion brand they were clients, so they would answer according to their relationship with that brand. We used TypeForm as the tool for data collection. 
BBR

16,2

180

A total of 622 valid responses were obtained after removing incomplete responses and outliers. We devided randomly this 622 subjects sample in two independent samples. A sample of 300 subjects was used on the first purification of the LCRP Scale (EFA). The respondents in this sample were between 29 and 39 years old (49\%), with college education and MBA (47\%) and with most of them having a relationship with the brand for five years $(30 \%)$, buying their products at least once a year $(56 \%)$.

Another sample of 322 responses was destinated to the new purification of the scale (CFA) and also used on Study 2. Most women in this sample were between 18 and 28 years old $(75 \%)$, with college education (47\%), clients of the brand for at least one year $(68 \%)$, with at least one purchase a year (42\%).

Thus, sampling procedures to the LCRP Scale development and validation process met all literature criteria. Figure 1 illustrates the methodological procedures of this research.

\section{RESULTS AND DISCUSSION}

\subsection{Study 1 - Development and validation OF THE LuXury Cus- tomer Relationship Perception Scale (LCRP Scale)}

Given that the scale development began with a construct definition, an extensive literature review on relationship marketing enabled us to define customer relationship perception and the aspects perceived by customers as relevant in their relationship with luxury fashion brands. The empirical understanding of this construct was achieved though interviews with

Figure 1 - Methodological procedures

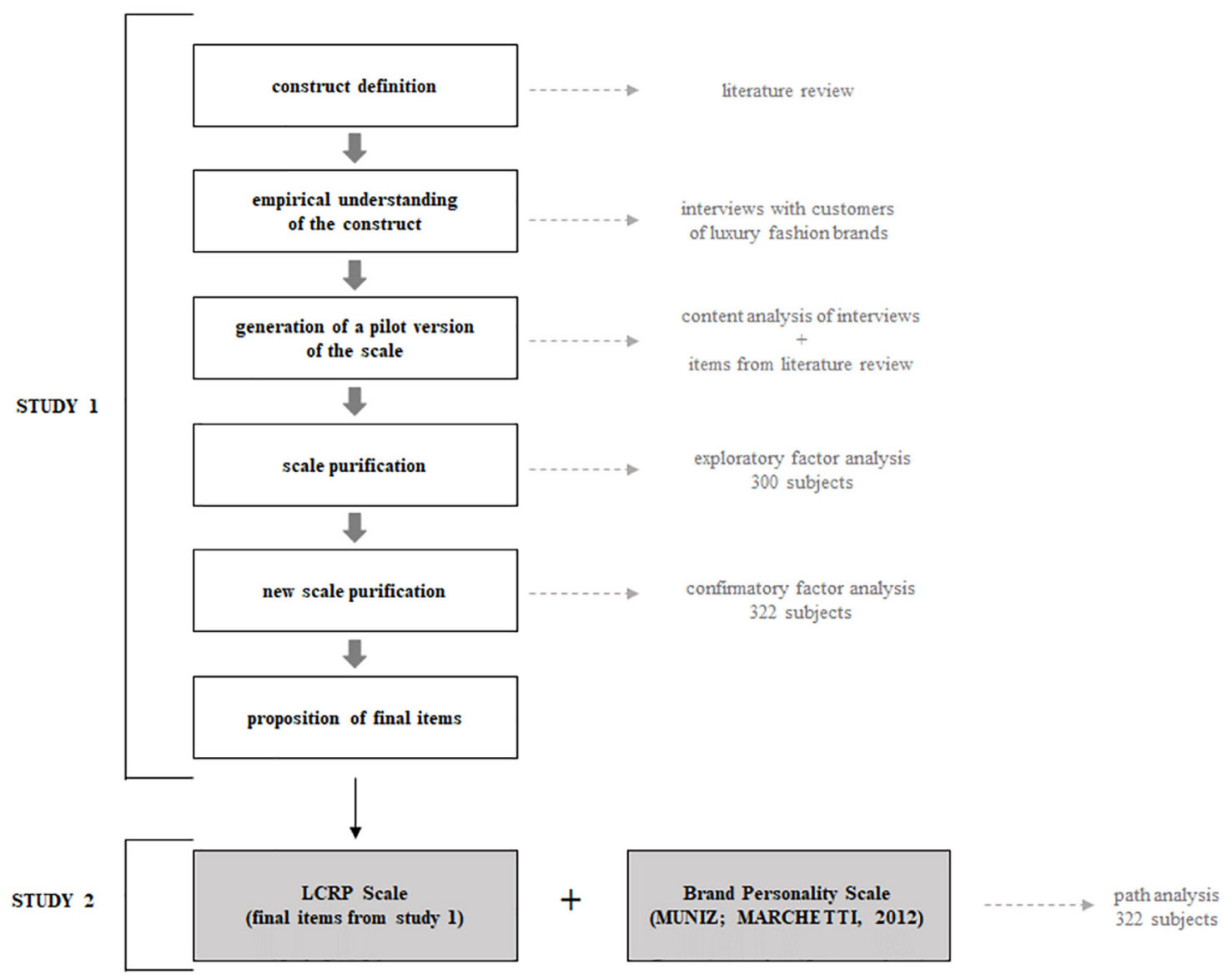


luxury female consumers, which helped us to develop an initial list of 32 items associated with customer relationship perception in luxury brands context.

To create the LCRP Scale pilot version, we added to these results 14 items of a previously validated scale that measures relationship perception (DEMO; ROZZETT, 2013). This pilot version of LCRP Scale had 46 items. After semantic analyses and judges' analyses, the final pilot version of the LCRP Scale had 40 items, which was submitted to scale purification.

Firstly, we performed the principal component analysis to verify the viability of using exploratory factor analysys (EFA) in our sample, or factorability, checking the correlation matrix and the measure of sampling adequacy proposed by Kaiser-Meyer-Olkin (KMO). Results indicated siginificant correlations between variables and high values for communalities, confirming the matrix's factorability for our sample. The KMO index reached 0.92 and was classified as "wonderful" according to Kaiser (1974). The criteria used were the eigenvalues, the percentage of explained variance, the scree plot graph, and the parallel analysis. All criteria indicated three factors to be extracted.

From this, we iniciated the EFA, with Promax oblique rotation, once behavioral studies assume correlation between variables (PASQUALI, 2012). Next, we tested the correlation between factors, observing a high correlation between them, what can be an evidence of a second-order factor. Pasquali (2012) states that if the arithmetic mean of the correlation of the factors is above 0.3 , there is the presence of a second-order factor, which is our case, once the mean of our three factors was 0.45 .

Considering that the three extracted factors are indicative factors of a second-order factor, a new principal component analysis was performed, revealing one factor, followed by another analysis conducted with only one factor. As a result, the scale obtained three first order factors. As a result, LCRP Scale obtained three first order factors, namely, Brand Experience, Customer Loyalty and Brand Image. The second-order factor was named Customer Relationship Perception and it is formed by the three first-order factors above.

Next, we evaluated the psychometric indices of the scale by its validity, reliability and total explained variance (HAIR et al., 2009). Scale validity was analized by checking the factor loadings of its items. Comrey and Lee (1992) indicate 0.55 as a minimum loading, explaining that loadings between 0.55 and 0.62 are classified as good; between 0.63 and 0.7 are very good; and higher than 0.71 are considered excellent. In this first purification, 17 from the 40 items of the pilot version of the scale were excluded, once they did not reach 0.55 loading. Hence, the LCRP Scale is an instrument composed of 23 items, with 10 being excellent, 2 very good, and 11 good items. Scale reliability was calculated through Cronbach's alpha, with good indicators: 0.89 for Brand Experience; 0.84 for Customer Loyalty; and 0.74 for Brand Image. Results above 0.70 are considered reliable and above 0.80 very reliable (NUNNALLY; BERNSTEIN, 1994). In addition, the three first order factors explain $45.8 \%$ of construct variance, which is considered a good factor solution by Hair et al. (2009).

The next step concerns a new purification of the LCRP Scale, when the 23 items from the previous stage are submitted to confirmatory factor analysis.

In order to check the dimensions of the scale, the one-factor and the multifactor models were tested and compared following parsimony recommendations (BYRNE, 2009). The one-factor model showed worse rates of adjustment $(\mathrm{NC}=6.18, \mathrm{CFI}=0.61, \mathrm{RMSEA}=0.13)$ when compared to the three-factor multifactorial model $(\mathrm{NC}=2.31, \mathrm{CFI}=0.90, \mathrm{RMSEA}=0.06)$. The three-factor model was found to outperform the one-factor model on all measures. In addition, the chi-square difference was significant $\left(\Delta \chi_{(3)}^{2}=661.27, \mathrm{p}<0.001\right)$, also indicating that the multifactorial model was indeed better than the unifactorial one. These results allow us to state that the scale is a good fit since all parameters meet the recommendations by Kline (2011). 
BBR

16,2

182
According to Coltman et al. (2008), the direction of causality from construct to items is the first evidence of a reflective model, as showed in Figure 2, which illustrates the measurement model obtained in the confirmatory factor analysis and its parameters. Other evidence are the high positive intercorrelations between items, observed in terms of factor loadings and reliability; and convergent and discriminant validity.

Factor loadings of the items from confirmatory validation ranged between 0.5 and 0.82 , revealing the items' good quality and, therefore, the scale's validity (HAIR et al., 2009). In this process, three items were excluded because they obtained low loadings: item 7 (the price of the products are fair), item 8 (this brand tries to know my needs) and item 24 (the advertising of this brand meets what the brand offers). The final structure of the LCRP Scale has 20 items distributed in the same three factors as those obtained in the exploratory analysis.

As an attempt to improve the fit obtained, the modification index (M.I.) was also analyzed in accordance with Kline's (2011) guidelines. The M.I. between I22 (This brand's stores are located at fancy addresses) and I23 (This brand's stores' ambiences are sophisticated) were 40.93 , which explains the double arrow between the items, indicating a positive correlation between them. There is theoretical support for this finding. Tungate (2009) points out that the luxurious atmosphere of physical stores of a luxury brand depends on its setting. In this context, Manlow and Nobbs (2012) shows that the main elements of a luxury store are their presence in big cities, the location in fancy or large shopping areas, a variety of products, the presence of exclusive products, contemporary ambiance installations, and the ability to communicate the sophisticated style of the brands.

Figure 2 - Three-factor model for the LCRP Scale.

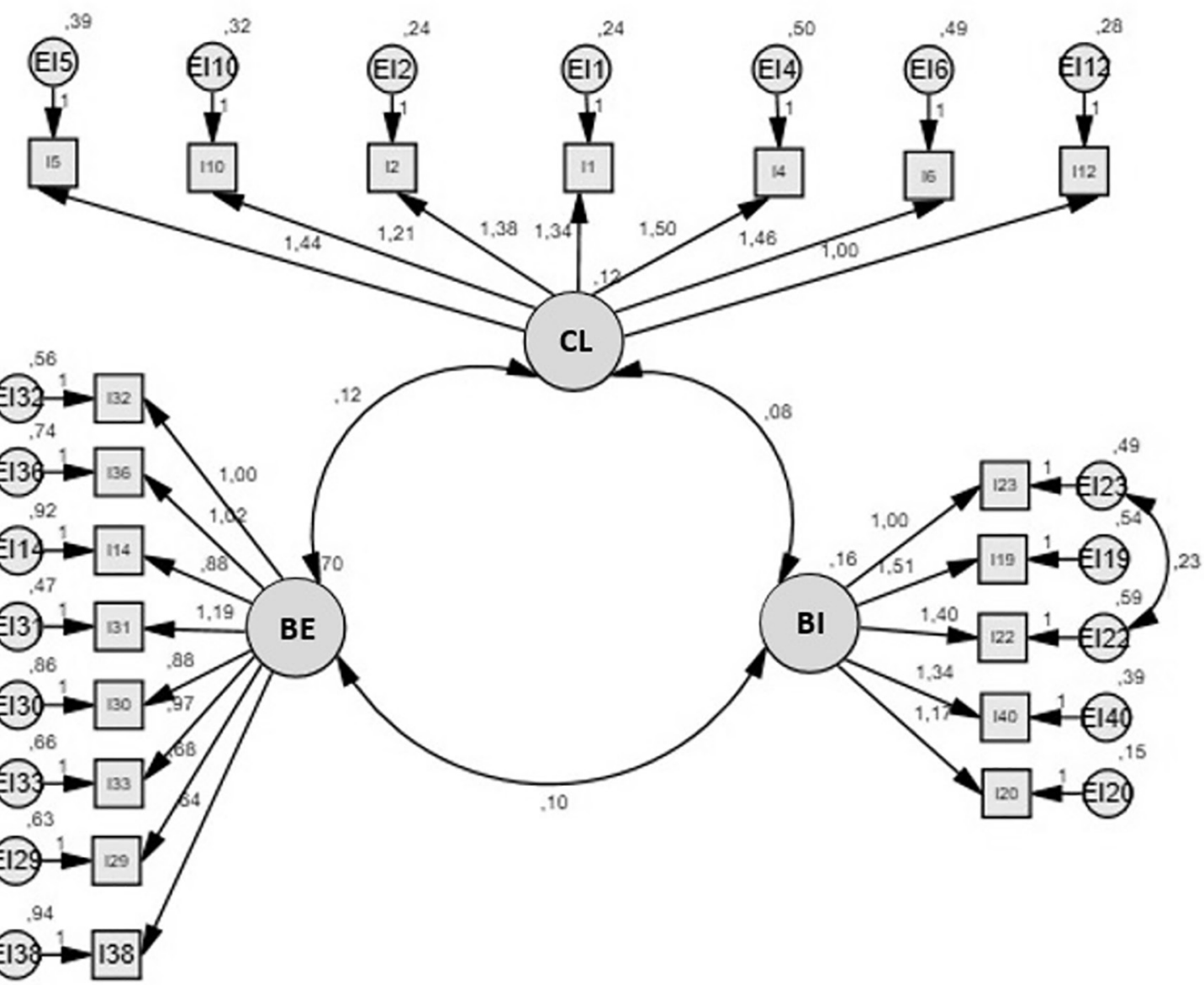

Note. $\chi 2(166)=382.72 ; \mathrm{p}<0.001 ; \mathrm{NC}=2.31 ; \mathrm{CFI}=0.90 ; \mathrm{RMSEA}=0.06$ 
Regarding reliability, the three factors were analyzed by Jöreskog's rho, a more accurate reliability measurement than Cronbach's alpha for CB-SEM, since it is based on factor loadings and not on observed correlations between variables (CHIN, 1998). The brand Experience factor obtained $\rho=0.86$; Customer Loyalty, $\rho=0.81$ and Brand Image, $\rho=$ 0.77 . These values are considered very satisfactory since the Jöreskog's rho index must be greater than 0.7 (CHIN, 1998).

Subsequently, construct validity for the LCRP Scale was tested by convergent validity, discriminant validity, and nomological validity. According to Hair et al. (2009), the first convergent validity evidence is the reliability of each factor; all of which were above 0.7 , indicating appropriate convergence. These authors mention factor loadings greater than 0.5 as another evidence, which occurred for all 20 items of the LCRP Scale, confirming the convergent validity of its factors. Discriminant validity evidence is apparent when the value of the extracted estimated variance of each factor exceeds the square of the correlation between them (values below the diagonal) according to the criterion by Fornell-Larcker (HAIR et al., 2009), which stated that a latent construct must explain its items' measures better than another construct. The discriminant validity has been confirmed, as shown in Table 1.

Nomological validity demonstrates the capacity of the scale to behave in relation to other constructs (HAIR et al., 2009). Therefore, it is necessary to test whether the correlations between the constructs make sense when compared to the theory. Literature shows a positive expectation of relation between the variables Brand Personality and Customer Relationship Perception. Thus, the nomological validity will be validated if the values obtained in the path analysis between brand personality and customer relationships are positive and significant. This evidence will be demonstrated in Study 2.

As the last step of a scale development process, Churchill (1979) and Rossiter (2002) indicate the proposition of final items. Table 2 presents the final version of LCRP Scale and its psychometric indices.

The main objective of this article was to investigate how Brazilians relate with luxury fashion brands. The interviews with customers during empirical understanding of the constructs give us first evidence. The experience is an important aspect that leads Brazilians to engage in relationships with brands from luxury sector, once they value excellence treatment, especially concening service care and personal interactions. It is important for Brazilians to know sales people, to be recognized by them and to be called by the first name, as an indication of intimacy.

Although it is more expensive to buy luxury fashion brands in Brazil comparing to the purchase in other countries, Brazilians prefer to buy in Brazil because of the relational benefits they have: payment convenience, product return or a more accessible exchange, receptiveness on problem solving and invitation for social events. Brazilians also demonstrate the need to talk to sales person and touch products, something not allowed in most countries, as related by the subjects. Evidence from this stage of the research revealed that the Brazilian customer's loyalty is linked to product and service quality, the feeling of intimacy and the sophisticated ambience of the stores.

The following analysis allow us to conclude that customer relationship perception in luxury fashion brands context in Brazil is a multidimensional construct, involving three

\begin{tabular}{llll}
\multicolumn{2}{l}{ Table 1 - Discriminant Validity } & & \\
\hline Factor & $\mathrm{BE}$ & $\mathrm{CL}$ & $\mathrm{BI}$ \\
\hline $\mathrm{BE}$ & $0,45^{\mathrm{a}}$ & - & - \\
$\mathrm{CL}$ & 0,17 & $0,39^{\mathrm{a}}$ & - \\
$\mathrm{BI}$ & 0,08 & 0,34 & $0,41^{\mathrm{a}}$
\end{tabular}

Note. ${ }^{a}$ extracted variance 
distinctive factors, namely, Brand Experience, Customer Loyalty and Brand Image. Statistical outcomes also inform that Customer Loyalty is the most central element to relationship perception of Brazilian customers in the luxury market.

These results find theoretical support in the relationship marketing model proposed by Grönroos (2017), composed by customers' value creating process, interaction process and communication process. The Brand Experience Factor refers to service encounters in the context of luxury brands, where special events, special services and exclusive products and treatments enable customers' value creation processes, as Grönroos (2017) says.

The Customer Loyalty Factor reveals customer trust on the brand, their willing to repeat purchase and to recommed the brand, in a scenario in which one has an identification with the brand. It corresponds to the interaction process that allows companies to mantain and develop relationships with customers in the long-term, according to Grönroos (2017). In addition, customer trust, customer satisfaction and loyalty are essential elements of relationship marketing (SCUSSEL et al., 2017).

Finally, the Brand Image Factor reflects the perceptions of the sophistication and refinement of stores, locations, and environments, refers to the quality of the brand and is affected by its credibility. This is in line with the communication process from Grönroos' model (2017), when the author presents a company's efforts to creat an image on consumers' minds, by a series of consistant messages.

Furthermore, these results corroborate the domain of luxury fashion brands exposed by Wu et al. (2015). The pre-purchase information seeking to validate Brand Image, revealing the brands' efforts in communicating with customers, giving them elements so they can make their purchase decision and start a relationship with the brand. Buying experience supports Brand Experience, representing service encounters and value creation propositions. Post-purchase treatment sustains Customer Loyalty, an attempt to maintain and enhance the relationship between customer and brand.

These outcomes suggest that customer relationship management in the luxury sector must consider not only marketing communication, product quality and after purchase strategies, but embrace functional and emotional aspects, in a holistic perspective, in which 
the customer feels safe and trusts the benefits that derive from the relationship with the brand. The literature endorses our findings: according to Grönroos (2017), in order to be successful, relationship marketing must be reinvented and encompass the whole interaction process - tangible and intangible aspects.

\subsection{VERIFICATION OF MODEL AJUSTMENT BETWEEN BRAND PERSONALITY AND CUSTOMER RELATIONSHIP PERCEPTION (STUDY 2)}

The relation between brand personality and customer relationship perception is illustrated by Figure 3.

Based on the parameters proposed by Kline (2011), the structural model tested revealed a satisfactory adjustment since the incremental index (CFI) was within the expected values. As for the absolute rates (NC and RMSEA), these were not within the reference values because they are sample size sensitive. The $\chi 2$ is a mathematical function that depends on the sample size (n); as $n$ increases, so does $\chi 2$, even when the differences between the matrices of variance observed and estimated are identical (HAIR et al., 2009).

With respect to the RMSEA, it is a more appropriate measure for confirmatory models since it increases their effectiveness (RIGDON, 1996). One can also surmise that the brand personality measure may have an adjustment problem since in its original validation (MUNIZ; MARCHETTI, 2012), much of the index did not show good fit, which may have contributed to the low absolute indices ( $\chi^{2}$ and RMSEA) in the test of our structural model. Thus, we chose to use the absolute adjustment of measurement known as the ajustment quality index (GFI), which is less sensitive to the sample size. According to Kline (2011), values close to 0.95 indicate good fit. Therefore, we concluded that the structural model shows that the influence of brand personality on relationship perception has a satisfactory adjustment. Finally, the strong correlations between brand personality dimensions and the factors of customer relationship perception confirmed the nomological validity of the LCRP Scale and its construct validity.

Results attest there is a prediction relation between brand personality and customer relationship perception, confirming the proposition by Fournier (1998) and Brito (2010) about

Figure 3 - Path analysis results

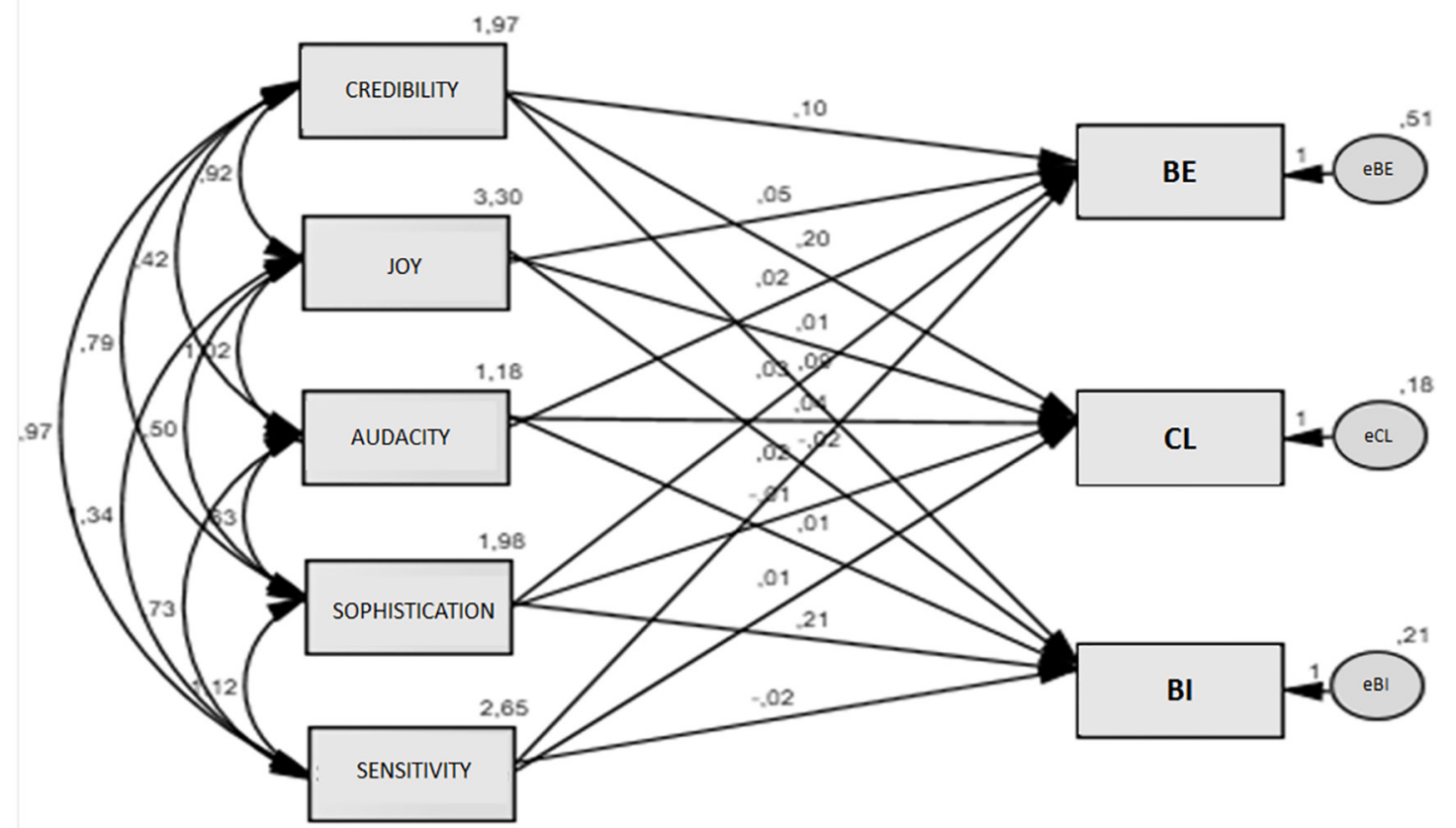


BBR

16,2

186

the influence character traits on relationships between customers and brands. Additionally, Credibility revealed strong correlations with all customer relationship perception factors, followed by Sophistication and its strong relation with Brand Image factor.

In regards to the interpretation given to the statistical significance of the determination of variance coefficient $\left(\mathrm{R}^{2}\right), 2 \%$ is a small effect, $13 \%$ is a medium effect, and above $26 \%$ is a large effect (COHEN, 1992). Therefore, the results demonstrate that Credibility contributes $10.8 \%$ to the explanation of Brand Experience, with little predictive power; with regard to Customer Loyalty, Credibility contributes $34.6 \%$ towards its explanation, revealing a great power of prediction. Finally, Brand Image can be explained by both Credibility $(\beta=0.21)$ and Sophistication $(\beta=0.51)$, the latter being a better predictor. These two dimensions have a great effect on explaining Brand Image (34.41\%).

The impact of credibility on brand experience indicates that when customers perceive brands as responsible, respectable and consistant, they are more likely to engage in experiences with the brand, they become more loyal and they have a better brand image on their minds. Tradition, brand history, high quality products and service excellence are essential characteristics of luxury brands (DUBOIS; LAURENT; CZELLAR, 2005). This allows us to say that when customers perceive these aspects, they will interact more with the brand, creating brand experiences.

Regarding the impact of Credibility on Customer Loyalty, the success of a brand in the luxury market is linked to its ability to build a consistent and distinct brand among competitors, and also knowing consumer preferences and adapting to them, which tend to foster customers' loyalty (CHEVALIER; MAZZALOVO, 2008). About the relation between Credibility and Brand Image, literature ensures that brand image is formed from signals emitted by the brand, which outline the perception the market has of it (BIEL, 1993). This author specifically points to the organization's image as a key element in shaping brand image.

On the relation between Sophistication and Brand Image, studies indicate that luxury consumption is associated with the pursuit of social status (KIM et al., 2016). On this matter, Lipovetsky and Roux (2005) affirm that luxury brands create sophisticated and refined environments, encompassing rare materials, exclusive services, architecture and careful setting of the stores. In addition, brand image sets the most important asset of a luxury brand and maintaining this position demands the continuous development of a sophisticated atmosphere (ALBRECHT; BACKHAUS; WOISETSCHLAGER, 2013).

\section{CONCLUSION}

This article presented an investigation on luxury fashion brands in the relational context. Two studies were conducted in order to achieve our objectives.

In the first one, we developed and validated a Luxury Customer Relationship Perception Scale to apprehend the perception Brazilian costumers have about their relationships with luxury fashion brands. Results show customer relationship perception in luxury sector as a multidimensional construct composed by three factors: brand experience, customer loyalty and brand image. This construct can be measured by the LCRP Scale, a 20 items instrument with theoretical consistency, reliability and construct validity.

In the second study, we evaluated the relation between brand personality and customer relationship perception. Such results demonstrate a prediction relation between them, confirming the effect of consumers' perceptions of brand character traits on the development of a relationship with a brand. On this matter, evidence allow us to say that the more reliable and sophisticated customers perceive a luxury fashion brand, the more likely they are to relate with the brand. 
Results from Study 1 reported customer loyalty as the main concept on customer relationship perception. In the same line, Study 2 points out Credibility as the most important dimension of brand personality impacting all customer relationship perception factors. These findings demonstrate that Brazilians relate with luxury fashion brands when they perceive they can trust the brand, the quality of their products, the level of service and the relational benefits they can derive from the relationship. Our evidence also bring to light that Brazilian customers want to feel that brands want to be part of their lives. In this sense, there is an emotional bonding related to cultural aspects that must be considered by luxury fashion brands when building a relationship with a Brazilian customer, once they have a unique relationship perception.

This article aimed to contribute with academic knowledge by presenting a research instrument under relationship marketing theory, the LCRP Scale, which will enable future investigations and relational studies with other marketing constructs. Our work also empirically confirms the impact of brand personality on customer relationship perception, filling up a literature gap. Thirdly, we explored luxury fashion brands in an emerging country, a topic of growing interest in literature, bringing out the relational aspects Brazilian customers perceive as relevant to build relationships with brands in luxury markets.

As limitations, the sample of customers for the interviews indicated a very similar profile between subjects, which could have generated bias in the results of the qualitative phase. However, it is important to mention that this limitation did not affect the generation of ite$\mathrm{ms}$ for the scale for the factorial analysis since all of the items generated in Study 1 went through semantic and judges' analyses, which were further corroborated by content validity in the literature. Another limitation is due to the cross-sectional nature of the study. In this sense, it requires the development of a time series database, followed by testing the LCRP Scale structure in a longitudinal framework, aiming at further refinement of the scale.

Regarding recommendations for future research, new validations of the LCRP Scale in other contexts and with different sample profiles should confirm the stability of the model and will increase its generalizability and external validity.

Our results are not conclusive, but they provide a useful starting point for carrying out further investigations that contribute to the progressive advancement of theoretical and empirical knowledge concerning relationship marketing in the luxury sector.

\section{REFERENCES}

AAKER, J. L. Dimensions of brand personality. Journal of Marketing Research, p. 347-356, 1997.

ALBRECHT, C. BACKHAUS, H.; WOISETSCHLAGER, D. M. Drivers of brand extension success: What really matters for luxury brands. Psychology \& Marketing, v. 30, n. 8, p. 647-659, 2013.

ARSENA, A.; SILVERA, D. H.; PANDELAERE, M. Brand trait transference: When celebrity endorsers acquire brand personality traits. Journal of Business Research, v. 67, n. 7, p. 1537-1543, 2014.

ATKINSON, R.; FLINT, J. Accessing hidden and hard-to-reach populations: Snowball research strategies. Social Research Update, v. 33, n. 1, p. 1-4, 2001.

ATWAL, G.; WILLIAMS, A. Luxury brand marketing-the experience is everything!. Journal of Brand Management, v. 16, n. 5-6, p. 338-346, 2009.

AZOULAY, A.; KAPFERER, J. Do brand personality scales really measure brand personality?. Journal of Brand Management, v. 11, n. 2, p. 143-155, 2003.

BARDIN, L. Análise de conteúdo. Lisboa: Edições, v. 70, 2011.

BECKER-OLSEN, K. L.; TAYLOR, C. R.; HILL, R. P.; YALCINKAYA, G. A cross-cultural examination of corporate social responsibility marketing communications in Mexico and the United States: Strategies for global brands. Journal of International Marketing, v. 19, n. 2, p. 30-44, 2011.

BIEL, A. Converting image into equity. In: AAKER, D. A., BIEL, A. (Org.). Brand equity and advertising: Advertising's role in building strong brand. Hillsdale, NJ: Laurence Erlbaum Associates, 1993. p. 67-82.

BIZARRIAS, F. S.; STREHLAU, S.; BRANDÃO, M. M. The moderating role of brands for low income luxury consumers. Independent Journal of Management \& Production, v. 8, n. 3, 2017. 
BBR

16,2

188

BRITO, C. Uma abordagem relacional ao valor da marca. Revista Portuguesa e Brasileira de Gestão, v. 9, n. 1-2, p. 49-63, 2010.

BYRNE, B. M. Structural equation modeling with AMOS: Basic concepts, applications, and programming. Routledge, 2013.

CAMPANARIO, P. M.; STREHLAU, S. Valor percebido do luxo: uma comparação entre Austrália e Brasil. Revista de Administração FACES, v. 15, n. 1, p 119-137, 2016.

CAPRARA, G. V.; BARBARANELLI, C.; GUIDO, G. Brand personality: How to make the metaphor fit?. Journal of Economic Psychology, v. 22, n. 3, p. 377-395, 2001.

CASTILLO-MONTOYA, M. Preparing for interview research: The interview protocol refinement framework. The Qualitative Report, v. 21, n. 5, p. 811-831, 2016.

CHEAH, I.; ZAINOL, Z.; PHAU, I. Conceptualizing country-of-ingredient authenticity of luxury brands. Journal of Business Research, v. 69, n. 12, p. 5819-5826, 2016.

CHEVALIER, M.; MAZZALOVO, G. Luxury brand management: a world of privilege. John Wiley \& Sons, 2008.

CHIN, W. W. The partial least squares approach to structural equation modeling. Modern Methods for BusinessRresearch, v. 295, n. 2, p. 295-336, 1998.

CHOI, E.; KO, E.; KIM, A. J. Explaining and predicting purchase intentions following luxury-fashion brand value co-creation encounters. Journal of Business Research, v. 69, n. 12, p. 5827-5832, 2016.

CHURCHILL, G. A. A paradigm for developing better measures of marketing constructs. Journal of Marketing Research, p. 64-73, 1979.

COHEN, J. A power primer. Psychological Bulletin, v. 112, n. 1, p. 155, 1992.

COLTMAN, T.; DEVINNEY, T. M.; MIDGLEY, D. F.; VENAIK, S. Formative versus reflective measurement models: Two applications of formative measurement. Journal of Business Research, v. 61, n. 12, p. 1250-1262, 2008.

COMREY, A. L.; LEE, H. B. A First Course in Factor Analysis. New York. 1992.

DEMO, G.; LOPES, C. Guaraná Antarctica e Cerveja Skol: Desenvolvimento e validação de escalas de relacionamento com clientes. In: Paulo Águas, Margarida Santos, Marisol Correia, \& Célia Ramos. (Eds.). Perspectivas Contemporâneas em Marketing. Portugal: TMS Conference Series, 183-199, 2014.

DEMO, G.; BATELlI, L.; ALBUQUERQUE, P. Customer Relationship Management Scale for Video Games' Players: Exploratory and Ordinal Factor Analysis. Revista Organizações em Contexto, v. 11, n. 22, p. 285-312, 2015.

DEMO, G.; ROZZETT, K. Customer relationship management scale for the business-to-consumer market: exploratory and confirmatory validation and models comparison. International Business Research, v. 6, n. 11, p. 29, 2013.

DIAMANTOPOULOS, A. The C-OAR-SE procedure for scale development in marketing: a comment. Internationl Journal of Research in Marketing, v. 22, n. 1, p. 1-9, 2005.

DUBOIS, B.; CZELLAR, S.; LAURENT, G. Consumer segments based on attitudes toward luxury: empirical evidence from twenty countries. Marketing Letters, v. 16, n. 2, p. 115-128, 2005.

FINN, A.; KAYANDE, U. How fine is C-OAR-SE? A generalizability theory perspective on Rossiter's procedure. International Journal of Research in Marketing, v. 22, n. 1, p. 11-21, 2005.

FOURNIER, S. Consumers and their brands: Developing relationship theory in consumer research. Journal of Consumer Research, v. 24, n. 4, p. 343-373, 1998.

FOURNIER, S.; ALVAREZ, C. Brands as relationship partners: Warmth, competence, and in-between. Journal of Consumer Psychology, v. 22, n. 2, p. 177-185, 2012.

GRÖNROOS, C. Marketing as promise management: regaining customer management for marketing. Journal of Business \& Industrial Marketing, v. 24, n. 5/6, p. 351-359, 2009.

GRÖNROOS, C. Relationship marketing readiness: theoretical background and measurement directions. Journal of Services Marketing, v. 31, n. 3, p. 218-225, 2017.

HAIR, J. F.; BLACK, W. C.; BABI, B. J.; ANDERSON, R. E.; TATHAM, R. L. Análise multivariada de dados. 6. ed. Porto Alegre: Bookman, 2009.

KAISER, H. F. An index of factorial simplicity. Psychometrika, v. 39, n. 1, p. 31-36, 1974.

KERVYN, N.; FISKE, S. T.; MALONE, C. Brands as intentional agents framework: How perceived intentions and ability can map brand perception. Journal of Consumer Psychology, v. 22, n. 2, p. 166-176, 2012.

KIM, D. H.; SUNG, Y. Gucci versus Old Navy: Interplay of brand personality and regulatory focus in advertising persuasion. Psychology \& Marketing, v. 30, n. 12, p. 1076-1087, 2013. 
KIM, S.; PARK, G.; LEE, Y.; CHOI, S. Customer emotions and their triggers in luxury retail: Understanding the effects of customer emotions before and after entering a luxury shop. Journal of Business Research, v. 69, n. 12, p. 5809-5818, 2016.

KLINE, R. B. Principles and practice of structural equation modeling. 3.ed. New York: The Guilford Press. 2011.

KO, E.; PHAU, I.; AIELLO, G. Luxury brand strategies and customer experiences: Contributions to theory and practice. Journal of Business Research, v. 69, n. 12, p. 5749-5752, 2016.

LAFFERTY, B. A.; GOLDSMITH, R. E.; HULT, G. T. M. The impact of the alliance on the partners: A look at cause-brand alliances. Psychology \& Marketing, v. 21, n. 7, p. 509-531, 2004.

LIPOVETSKY, G.; ROUX, E. O luxo eterno: da idade do sagrado ao tempo das marcas. Editora Companhia das Letras, 2005.

MALÄR, L.; NYFFENEGGER, B.; KROHMER, H.; HOYER, W. D. Implementing an intended brand personality: a dyadic perspective. Journal of the Academy of Marketing Science, v. 40, n. 5, p. 728-744, 2012.

MANLOW, V.; NOBBS, K. Form and function of luxury flagships: An international exploratory study of the meaning of the flagship store for managers and customers. Journal of Fashion Marketing and Management, v. 17, n. 1, p. 49-64, 2013.

MUNIZ, K. M.; MARCHETTI, R. Z. Brand personality dimensions in the Brazilian context. Brazilian Administration Review, v. 9, n. 2, p. 168-188, 2012.

NOBRE, H.; BRITO, C. Brand relationships: A personality-based approach. Journal of Service Science and Management, v. 3, n. 2, 2010.

NUNNALLY, J. C.; BERNSTEIN, I. H. Psychometric theory. 3.ed. New York: McGraw-Hill,1994.

OLIVEIRA, M. L. M. M.; VELOSO, A. R. Dysfunctional consumer behavior: Proposition of a measurement scale. Brazilian Business Review, p. 24, 2015.

PARK, C. W.; EISINGERICH, A. B.; PARK, J. W. Attachment-aversion (AA) model of customer-brand relationships. Journal of Consumer Psychology, v. 23, n. 2, p. 229-248, 2013.

PARK, J. K.; JOHN, D. R. Capitalizing on brand personalities in advertising: The influence of implicit selftheories on ad appeal effectiveness. Journal of Consumer Psychology, v. 22, n. 3, p. 424-432, 2012.

PASQUALI, L. Análise fatorial para pesquisadores. Laboratório de Pesquisa em Avaliação e Medida (LabPAM) - Instituto de Psicologia. Brasília: Universidade de Brasília, 2012.

RIGDON, E. E. CFI versus RMSEA: A comparison of two fit indexes for structural equation modeling. Structural Equation Modeling: A Multidisciplinary Journal, v. 3, n. 4, p. 369-379, 1996.

ROSSITER, J. R. The C-OAR-SE procedure for scale development in marketing. International Journal of Research in Marketing, v. 19, n. 4, p. 305-335, 2002.

ROUX, E.; TAFANI, E.; VIGNERON, F. Values associated with luxury brand consumption and the role of gender. Journal of Business Research, v. 71, p. 102-113, 2017.

ROZZETT, K.; DEMO, G. Desenvolvimento e validação fatorial da escala de relacionamento com clientes (ERC). Revista de Administração de Empresas, v. 50, n. 4, 2010.

SCUSSEL, F. B. C.; DEMO, G. Personalidade de Marca: Itinerários da Produção Nacional e Agenda de Pesquisa. Revista Brasileira de Marketing, v. 15, n. 3, p. 340, 2016.

SCUSSEL, F. B. C.; PETROLL, M. L.; SEMPREBON, E.; ROCHA, R. A. O que é, afinal, Marketing de Relacionamento? Uma Proposta de Conceito Unificador. Revista de Ciências da Administração, v. 19, n. 48, p. 9-23, 2017.

SEO, Y.; BUCHANAN-OLIVER, M.; CRUZ, A. G. B. Luxury brand markets as confluences of multiple cultural beliefs. International Marketing Review, v. 32, n. 2, p. 141-159, 2015.

SOUZA NETO, A. F.; MELLO, S. C. B. Características dos relacionamentos estabelecidos em diferentes contextos de serviços sob a ótica do consumidor. Revista de Administração de Empresas, v. 49, n. 3, 2009.

STATHOPOULOU, A.; BALABANIS, G. The effects of loyalty programs on customer satisfaction, trust, and loyalty toward high-and low-end fashion retailers. Journal of Business Research, v. 69, n. 12, p. 58015808, 2016.

TABACHNICK, B. G.; FIDELL, L. S. Using multivariate statistics. 6.ed. Boston: Pearson Allyn And Bacon, 2013.

TUNGATE, M. Luxury world: the past, present and future of luxury brands. Kogan Page Publishers, 2009.

VASCONCELOS, H.; DEMO, G. Enchant to retain: an instrumental study about the relationship between Walt Disney World Parks and its Brazilian customers. Anais do International Conference on Industrial Engineering and Operations Management, Guimarães, Portugal, 18, 2012. 
WONG, A.; SOHAL, A. Customers' perspectives on service quality and relationship quality in retail encounters. Managing Service Quality, v. 12, n. 6, p. 424-433, 2002.

WU, M.S.; CHANEY, I.; CHEN, C. S.; NGUYEN, B.; MELEWAR, T. C. Luxury fashion brands: factors influencing young female consumers' luxury fashion purchasing in Taiwan. Qualitative Market Research, v. 18, n. 3, p. 298-319, 2015.

We state there are no conflit of interest and all the authors were involved in every step of research planning, execution and writing. 